\title{
'Liking and Sharing' the Stigmatization of Poverty and Social Welfare: Representations of Poverty and Welfare through Internet Memes on Social Media
}

\author{
Kathy Dobson* and Irena Knezevic** \\ *School of Journalism and Communication, Carleton University, Ottawa, Ontario, \\ Canada, KathyDobson@cmail.carleton.ca
}

${ }^{* *}$ Carleton University, Ottawa, Ontario, Canada, irena.knezevic@carleton.ca

\begin{abstract}
Internet memes play an important role in the reproduction, reinforcement and circulation of social stereotypes, including those about people who live in poverty. In this paper we investigate the relationship between Internet memes and stereotypes about poverty by examining a set of memes that make claims about one particular aspect of poverty in highincome countries - receipt of social assistance in the form of welfare cheques, medical coverage and food. We apply critical discourse analysis to a set of widely circulated poverty memes to identify how notions of individual responsibility and deservedness surface in these messages. Whereas the memes in our sample consist of both visual and textual elements, we found that the text was decidedly more important for reproducing stereotypes linked to the abstract neoliberal values of individual responsibility and participation in market economy.
\end{abstract}

Keywords: Poverty, Social Welfare, Memes, Social Media, Stigmatization, Viral

Acknowledgement: Kathy Dobson gratefully acknowledges the Vanier Canada Graduate Scholarship program for its generous financial support of her research.

With the rapid growth of multimodal content in social media, circulation of Internet memes on social media platforms has become a major way of reproducing and reinforcing, ideas and meanings. At the same time, poverty remains a powerful form of social marginalisation, one that is often misunderstood and stereotyped. In this paper we investigate the relationship between Internet memes and stereotypes about poverty. We examine a set of memes that make claims about one particular aspect of poverty in high-income countries - receipt of social assistance in the form of welfare cheques, medical coverage and food stamps. We concentrate on the specific issue of social assistance because in our scoping searches it appeared to generate the majority of poverty-bashing memes; presumably, people create memes about social assistance as it is representative (to them) of the 'problem' of the poor: lazy, dishonest cheats who abuse government assistance and refuse to help themselves. We focus on poverty in high-income countries for two reasons. Firstly, in places where the average standard of living is relatively high, those living in poverty are more likely to be blamed for their condition, as the reasons for their poverty may be less obvious. Secondly, the neoliberal ideology which emphasises personal responsibility is highly prevalent in economically advanced countries.

We situate our work in two bodies of scholarship: literature on memes and Internet virality, and literature on portrayals of poverty in the media. We frame our research 
theoretically and methodologically in the tradition of critical discourse analysis. We analyse 59 text-and-image memes to identify key themes manifested in this content. We conclude by suggesting that our empirical findings carry significant social and theoretical implications as to how, as a society, we perceive those living in poverty in high-income countries.

\section{Memes and Internet Virality: How and Why Things Go Viral Online}

On May 22, 2007, the parents of two young boys uploaded a family video to YouTube that showed their older son's finger being bitten on camera by 'Charlie', the younger baby brother. In what would become one of the most famous lines of YouTube (Shifman 2011), the older brother suddenly cried out, "Charlie bit my finger!" Within days the video was viewed by over a million unique viewers, and in February 2016 the figure stood at 835,413,706 views. This represents just one example of what Shifman (2011) describes as a video that went 'viral' on the Internet, in a study that examined 30 such videos to identify commonalities that play a role in helping a video, text, or image to go viral. These commonalities include humour (Knobel and Lankshear 2007; Shifman 2011), and memes which feature 'ordinary' people, particularly those featured on YouTube (Burgess and Green 2009; Lange 2009) as demonstrated by the "Charlie bit my finger!' video. Further, simplicity and repeatability were identified as key: since it conveys a single idea or concept, a meme which features a message that is easily understood is more likely to go viral.

'Meme' is a term that is today commonly attributed to viral Internet content, but the term predates the widespread use of the Internet and covers a much broader cultural phenomenon. In 1976 biologist Richard Dawkins first coined the term 'meme', defining it as "a unit of cultural transmission, or a unit of imitation" (2006/1976, 194), which, similar to a gene, replicates and mutates. Dawkins argues that, "cultural transmission is analogous to genetic transmission in that [...] it can give rise to a form of evolution" (Ibid., 191). Although the definition of 'meme' is still debated (Kwasnik and Crowston 2005; Shifman 2014) the term is now commonly used to refer to an image, video or hyperlink via digital platforms that carries specific cultural meaning, spreads rapidly and can also evolve (Berger and Milkman 2010; Knobel and Lankshear 2007). More colloquially, Internet memes are known as still images with a simple commentary or caption (Hadley 2016), as a Google search for "Internet memes" will reveal. It is this specific type of meme - simple and facilitated by social media platforms - that is the focus of our study.

Thanks to social media such as 4chan, Facebook, Twitter, Instagram, Tumblr and Reddit, anything and everything on the Internet, which now has over three billion users worldwide, has the potential to reach an enormous audience. Facebook users alone now total more than one billion worldwide (Statista 2016). This means that when something has 'gone viral' it has spread quickly and widely across the Internet, with millions of people exposed to the same image, video, or text (Heylighen 1996). Hristova posits that memes emerge at "moments of contestation of dominant narratives and through their participatory structure of imitation and mutation, they allow for the dissolution of points of ideological conflict as well as for the reestablishment of a normative narrative" $(2014,265)$.

This reestablishment of a normative value includes the reproduction of negative stereotypes that are commonly held about those living in poverty for public commentary through poverty-bashing memes. As will be shown below, some memes do the subtle work of spreading not just the text-image messages themselves, but also the underlying values and judgments. As Yoon (2016) found in analysing racist memes, 
memes are a site of ideological reproduction; they not only reflect stereotypes, but also impact the way people understand them.

Some scholars have noted that analysis of memes can offer insight into the public's reaction or position on a wide range of issues (Milner 2013a; Nahon and Hemsley 2013; Shifman 2013) and memes can increase participation in public discourse (Jenkins 2006). This raises a question of what these widely circulated poverty-bashing memes say about our normative values when it comes to those living in poverty. As Shifman (2011) posits, despite the unique ability of digital culture and technological advances to create the potential for memes to go viral, human agency still plays a crucial role in enabling the widespread distribution of specific images, videos and text. A meme needs to appeal to a large and wide audience in order to go viral, as this audience needs to circulate and recirculate it. A meme's broad appeal is usually the result of the clever use of humour, featuring 'ordinary' people and familiar narratives, or simply offering the viewer an opportunity to feel better about themselves as the result of watching someone else's 'fail' (Shifman 2011).

However, memes can also influence discourse on all kinds of social issues and values and, more than simply reinforcing pre-existing stereotypes, can also change how some people think (Davis et al. 2016; Nahon and Hemsley 2013). For example, when multiple memes appear and circulate, and all repeat the same theme and message, their cumulative effect adds to the impact and influence of each one (Nahon and Hemsley 2013; Segev et al. 2015). This also reinforces normative values about the themes and messages being circulated, and can contribute to their ability to go viral. As Segev et al. (2015) argue, these widely shared and circulated memes "feed off each other to create a multilayered conversation about a specific theme... [and] their articulation as multiparticipant discussions adds to their powerfully participatory rhetoric" (Ibid., 431).

Clearly, technology alone is not what makes a meme go viral. Although the Internet enables a meme to go viral, reaching a potential audience of millions within hours, the right cultural conditions are also necessary for a meme to spread rapidly and widely across social media (Nahon and Hemsley 2013). For example, if one were to examine what has gone viral at any given time, one would have a snapshot of what is considered of consequence to a specific society at a specific time (Baym 2010; Nahon and Hemsley 2013). Nahon and Hemsley (2013) posit that "because viral events arise out of the complex interactions of many actors - individuals, companies, government - as well as the social and cultural contexts within which they are embedded if one wants an indication of what is important ... virality... can become a way of documenting the fabric of societies" (Ibid., xii). When something goes viral, it signifies that a large "collective voice of the crowd" is saying, "this is important" (Ibid., xii).

What can an examination of memes tell us about our society's values and attitudes towards those living in poverty? Specifically, what about memes that typically replicate and reinforce negative stereotypes (such as presenting those living in poverty as guilty of welfare fraud, laziness, drug and alcohol abuse) and generally criminalise poverty? In addition to offering a mirror of public opinion, Shifman (2014) posits that memes play a crucial role in the formation of public opinion in the public sphere. Others argue that some memes are even harmful and potentially contribute to the oppression of others (Kien 2013; Nichols 2003).

As noted by Marwick, memes not only embody today's popular online culture, they also exemplify what Godin termed the 'idea virus,' which "spread[s] from person-toperson without any push from the creator" $(2013,13)$. Therefore, the way in which 
those living in poverty are represented online in memes, in particular those which are most popular and widely circulated, both contributes to and influences public discourse on this issue, and also offers insight into the social construction of poverty in our society.

\section{Portrayals of Poverty in Mainstream and Social Media}

There is an increasing interplay between news and social media coverage of events and issues. As Broersma and Graham (2012) argued in their analysis of the relationship between Twitter and news coverage of the 2010 British and Dutch elections, information is increasingly produced, aggregated and circulated through online channels, and then taken up and reproduced in journalistic discourse. Representations through memes of people living in poverty, then, have potentially increased currency and reach in this networked media environment. Contemporary analyses of poverty point to neoliberal ideology at the root of public perceptions of those who live in poverty (Knezevic et al. 2014). Neoliberal political and economic order emphasises free markets and policies "aimed at the labour market supply in direct response to labour need" (MacKinnon 2013, 22). Treating citizens as primarily a source of labour, neoliberal ideology consequently values individualism, citizens' responsibility, and a "commodified measure of citizenship' which leaves little room for 'collective solidarity" (Marston 2008, 362). In other words, critiques of neoliberalism point out that the continued social marginalisation and 'bashing' of those who live in poverty serves a particular political economic purpose of reproducing citizens as individual producers and consumers. This process ensures that poverty is constructed as an individual rather than a systemic issue. That perception is so pervasive and so deeply entrenched in common social norms that even those who live in poverty often internalise such views and make self-blame part of their self-identity (Power 2005).

This portrayal of poverty is frequently reproduced in various media formats; a vast literature has identified poverty stereotyping in traditional media, including news reporting and entertainment content. Less is known about how the stereotypes are reproduced in social media, but given that social media have become the dominant source of information for many users (Reuters Institute 2016) this seems worth investigating.

The literature on poverty representations in the news media often argues that the media act as a key conduit of information and play a major role in forming collective public opinion, acting as a primary definer of social issues. As such, what the public believes about those living in poverty is often formed and reinforced by mainstream media dialogue and presentation of those living in poverty (Bullock et al. 2001; Cunningham 2004; Fleras 2011; Kim and Loury 2014; Lens 2002; Lister 2004; Mosse 2010; Nielsen 2008; Redden 2011; Swanson 2001).

The literature analysing media coverage presents journalists and mainstream news media as an important source of confirming and perpetuating negative stereotypes of those living in poverty and, as a result, further stigmatising them (Lister 2004). Some of the research highlights that by circulating stereotypical images of the 'welfare mother' in television shows - depicting them as lazy, inclined to having excessively large families, and as 'bad' mothers, for example - further contributes to the public's perception that people living in poverty are at fault for their financial circumstances due to individual character flaws and weaknesses, as opposed to structural constraints (Bullock et al. 2001; Kelly 2010). As Bullock et al. remark: "Framing techniques that present poverty as an individual problem rather than a societal issue 
rooted in economic and political inequality further reinforce the perceived undeservingness of the poor" $(2001,237)$.

In addition to the literature which criticises the media for its stereotypical framing of those in poverty as welfare 'cheats' and 'undeserving poor', some scholars contend that there is also often an absence of media coverage about issues regarding social assistance and those living in poverty, which arguably suggests to the general public that welfare assistance is not an important issue (Kelly 2010). Even when the mainstream media do report on issues of vital importance with regards to those living in poverty, "journalists rarely address the poor as their imagined or implied audience" (Nielsen 2008, 605). This, some scholars argue, is because those in poverty are not part of a profitable demographic or user base for mainstream media news to appeal to, and therefore they are simply ignored as an audience (Fleras 2011; Herman and Chomsky 2002).

Analysis of media framing in television images and print media makes it clear that those living in poverty are not always just presented as negative stereotypes of the 'lazy welfare cheat' but in fact are often also depicted in a sympathetic or even neutral tone. However, these depictions and framing of the 'poor', however stereotypical, sympathetic or neutral, still lack the complexity necessary in order to educate the public about the root causes of poverty, failing to contextualise poverty or offer insight into its systemic causes (Bullock et al. 2001). With social media now also considered an important, and, for many users, a sole source of information and news, its potential impact on how events and social issues are framed should not be underestimated (Duggan 2015; Westerman et al. 2014. According to Pew Research Center (2015) more than $70 \%$ of Internet users in the US are also Facebook users. Other social media, including Instagram, Twitter, and Pinterest, although not as popular as Facebook, also have millions of regular users (Duggan 2015). According to the Pew Research Internet Project (2015), almost half (49\%) of Instagram users visit the site daily; $70 \%$ of Facebook users not only visit the site daily, almost half $(45 \%)$ visit the site more than once each day, and $52 \%$ of those online visit multiple social media sites each day. Westerman et al. (2014) have found that "social media are being used to seek information about serious topics", and users often use social media as a forum and platform for public discourse about social concerns, important issues and stories (Ibid., 171).

Although mainstream media have traditionally been considered one of the most trusted credible sources for informing the public on news and important issues of the day, social media has increasingly begun to fulfil this role as well (Westerman et al. 2014). In fact, when technology becomes disrupted during certain events, whether due to a natural disaster such as an earthquake, or a military crisis, and satellite connections are temporarily disabled for example, social media can play "a key role in disseminating information". According to Westerman et al., "social media are gaining prominence as an information source in disaster and risk time even though the accuracy of the information shared through this channel is often unclear" (Ibid., 172). Westerman et al. question how people assess the credibility of social media stories and news reports and suggest that with the increasing popularity of new media, and the resulting lack of "uniformity in content quality," social media users need to be more critical of the news they consume (Ibid., 173). Some scholars argue that social media's role in any kind of social upheaval has been overstated (Johnson and Halegoua 2015) and perhaps even exaggerated, and that "mass media and social platforms can hardly be seen as separate forces when it comes to controlling information and communication processes" (van Dijck and Poell 2013, 11). 
However, with the number of Internet users worldwide now standing at over three and a half billion, each spending an average of almost eight hours online every single day, and 1.5 billion of those users being active on Facebook (Statista 2016), "these Internet memes also have the power to significantly influence a community's social values" (Chen 2012). Social media is only increasing in its ability to reach, and potentially impact and influence, an incredibly large audience, and although "the internet has been examined as a utilitarian space for social movements, it also acts as a cultural space for personal and community expression about important social issues" (Mina 2014, 359). As Mantler (2010) posits, media framing of social issues has a large influence in the public's perception of important social issues, and the media often replicates class rhetoric. Moreover, the participatory nature of social media complicates the relationship between ideology and personal agency. When traditional media propagate ideologies, they can easily be understood as shills for the elites, but the motivations of social media participants are likely more hegemonic, and surely more diverse and more complicated.

Despite the large audience online, a gap in the literature exists with regards to how social media represents, and arguably stigmatises, those living in poverty; this lack of research is especially apparent concerning memes specifically. Although the creators of specific memes are often unknown (Nooney and Portwood-Stacer 2014), the meaning-making of memes can reveal insight into our cultural and social values in numerous ways (Shifman 2013). What does it say about our social values that millions of people view the 'People of Wal-Mart' page on Facebook on a regular basis, often posting cruel and disparaging remarks dedicated to mocking the people featured who are obviously disadvantaged? According to Koenig and Rustad (2015, 596) "social media amplifies stereotypic images of the poor that undermine their economic and educational opportunities" and "divide persons into 'deserving' and 'undeserving' categories based on their competency at online impression management". The People of Wal-Mart website exists to mock, "the poorly dressed [...] and the less educated" (Ibid., 597). This representation of people living in poverty who shop at Wal-Mart as being objects of ridicule and humiliation is enormously popular, viewed online by millions and often circulated throughout social media (Ibid.).

According to Koenig and Rustad (2015), Facebook is also the site of other sources of postings dedicated to humiliating people living in poverty, and this content carries the power to reinforce negative stereotypes about those living in poverty, including pages dedicated to encouraging support for mandatory drug testing of welfare recipients, and critiquing the spending habits of those who receive social assistance. In other words, social media is often not a friendly or supportive environment for those who are economically disadvantaged, and in fact, often represents a hostile environment for those living in poverty. Recent research by the Reuters Institute for the Study of Journalism at Oxford University includes a survey about the online habits of more than 50,000 people in 26 countries, and reveals that although mainstream media remains an important source of news and information, the "majority of people now use social media for news, with one in ten saying it is their main source" (Reuters Institute 2016, 4).

\section{Methodology}

This research uses Critical Discourse Analysis (CDA) to analyse the study sample. In particular, we use the CDA approach to link the themes found in our sample memes to the broader sociopolitical context of neoliberalism. 
The CDA approach critiques neoliberalism by examining how people are constituted as subjects in the neoliberal order (Knezevic et al. 2014). Discourse is a set of communication practices that reflect a particular way of thinking. This includes language but also other forms of expression, including visual communication, built environments and social cues. Studies using CDA analyse the role of discourse in perpetuating the neoliberal order by reinforcing the tenets of neoliberal ideology - individual responsibility and primacy of market economy. The resulting cultural reproduction - how the ideological tenets are reproduced in media and popular communication - is an essential pillar of the neoliberal project (Fairclough 2000).

Poverty is a widespread problem experienced in diverse and often relative ways. In this study we focus on memes that address those living in poverty in economically advanced contexts and more specifically those who receive some form of social assistance (e.g., welfare, Medicare or food stamps). The study does not include global poverty, nor recent immigrants and refugees to high-income countries, who may or may not be also living in poverty. These subjects warrant their own studies as they involve a range of other political and social assumptions and stereotypes.

Interested in widely circulated memes, we selected our sample by first going into incognito (private) browser mode to ensure our search results were not influenced by past searches. We then conducted a search for "welfare memes on Facebook" in Google images. We recognise that the Google search results may not be an accurate representation of what is more widely circulated on Facebook. However, this approach to data collection is easily repeated, and our assumption is that these are the results that anyone can access easily (with just Internet access) and for free. In other words, this approach to data collection did not require paid access to historical data on a social media platform, nor did it require being embedded in a network of social media users likely to circulate such material. It can be easily replicated, which we believe is an advantage of this particular data collection method.

The search was conducted on 31 March 2016, and resulted in hundreds of images to choose from. The Google search engine uses a trademarked algorithm called PageRank to determine how it ranks search results. Although specific details about its algorithm are a company secret, Google ranks a search based on several factors, but the frequency of a search result and the number of web pages that link to a particular site or image determines its importance in the ranking ${ }^{1}$. We thus determined that ranking was indicative of how viral (culturally reproduced) each of our search results was, suggesting that each image in our sample would in fact qualify as a meme.

After viewing the first top four hundred memes from the Google search, we estimated that saturation was easily reached within the first few dozen images; that is, additional images seemed to repeat similar messages and a smaller sample was enough to identify to key themes in the search results. We selected the first 100 search results and eliminated any irrelevant search results (for example, a sketch of person holding grocery bags with the caption "Today I bought some mustard, eggs, seasoning salt, bologna, and some cooking oil... Good night, Facebook"). This left us with a sample of 59 images.

In keeping with the CDA tradition, we looked for messages reflective of neoliberal values. Specifically, we looked for the values of individual responsibility and deservedness. As noted above, the literature on portrayals of poverty commonly links these values to the ways in which poverty is perceived in neoliberal contexts. More nu-

${ }^{1}$ How Stuff Works: http://computer.howstuffworks.com/internet/basics/google1.htm 
anced interpretation of these values includes notions of personal failure, consumerism, and the need for individuals to participate in market economy by earning their material necessities.

We relied on the textual components of the memes, while also considering the visual elements of the meme discourse. In other words, our primary analysis was concerned with the textual 'face value' of each meme in the sample, and this analysis was also informed by the images that accompanied the text. Whereas memes "braid text and image" (Milner 2013b, 2363), and CDA research increasingly looks to multimodal analysis (van Leeuwen 2009; Wang 2014), particularly in the social media domain (KhosraviNik and Unger 2015), text was decidedly more important in our sample. Some stereotypes - racialised and gender-biased messages, for instance are easily expressed visually. Others, such as judgements regarding the neoliberal notions of personal responsibility, are more abstract. Thus, while the memes in our sample are without doubt multimodal, their key messages are contained in the text, and their visualised format is simply a vehicle for distributing them. Instead of text "anchoring" the image (Barthes 1977) the images, where they are relevant, anchor the text. For some memes in our sample, the image helps direct our interpretation of the text. In others the image is less relevant or even completely absent.

The present authors open-coded the memes in the sample, creating categories through an iterative process. We determined the key themes and then coded the memes individually. We then compared our coding, developing consensus on any individual memes we coded differently. We agreed on five key themes: welfare fraud; lazy welfare recipient; undeserving poor, punitive of the poor, and finally, memes that are critical of the larger system in which social assistance exists. We also noted an additional thread that was evident to a lesser or greater extent in all of the categories and most of the memes. That thread was the tone of victimhood where the ostensive creator of the meme feels victimised - he or she works hard to pay for those who are lazy, undeserving, fraud-prone and should be punished. This tone was present in many of the memes in our sample; however, it was most evident in the memes we coded under "undeserving" and "lazy" themes. It seemed to invite resentment over the alleged shortcomings of the recipients of social assistance. However, as this thread was more indicative of how the meme creators saw themselves, rather than how they saw those in receipt of assistance, we eliminated this category in our final coding, retaining only the five themes that directly related to the portrayal of those living in poverty. We also considered the importance of visual semiotics analysis (Harrison 2003), but found that the textual discourse was much more deliberate in our sample and deserved our full attention. In the next section we describe and discuss our findings, and using the lens of CDA situate these themes in the larger context of neoliberal discourse surrounding poverty.

\section{Analysis}

Of the 59 memes we analysed we ended up with 87 codes, where some memes were coded under more than one theme. The results are as follows:

- Welfare fraud meme: 15

- Lazy welfare recipient meme: 23

- Undeserving poor meme: 24

- Punitive of the poor meme: 8

- Critical of the larger system meme: 17 
There are six memes that overlapped between the first three categories (welfare fraud, lazy welfare recipient and undeserving poor meme) and eight that overlapped in two categories, the undeserving poor meme and lazy welfare recipient meme. The six memes that overlapped between the welfare fraud, undeserving poor, and lazy welfare recipient all mention the word 'welfare', and five of the six make direct reference to (mis)spending of social assistance money on tattoos, smartphones, cable TV, expensive luxury items such as designer purses or shoes, and not having a job. They all suggest welfare fraud, the poor being undeserving, and those on welfare being 'lazy'. One meme in particular manages to exemplify every poverty-bashing meme in our sample, accusing the person portrayed in the meme as receiving public assistance as lazy, dishonest, and undeserving. It shows a picture of a young woman who appears to be able-bodied (though we do not know of course who this person is, as the picture could have come from anywhere) and the text next to her states:

- receives over $\$ 1,200$ a month in public assistance

- has four children by 4 fathers

- has been on Public Assistance for 12 years despite being in perfect health and capable of working has no desire to find a job because, "The government gives me money."

- has sold her food stamps for "free money"

- she intends to become pregnant again, so that she can receive MORE welfare money

- pays no taxes. When asked, she believes that she is entitled to government money aka YOUR TAX DOLLARS. ${ }^{2}$

There are eight memes that overlap in two categories. Four of those overlap in the welfare fraud and undeserving poor memes. Each of the four include the word 'welfare' and suggest both welfare fraud and that the person on social assistance is somehow undeserving. The one which exemplifies this the best (number 33) is titled, "Need a Pre-nup for my food stamps: Food stamp fail." The meme is text only, with no picture, and it states:

Look I've been on the list for section 8 ever since I was 18 when I had my 2nd child and now Welfare is paying for me to take a medical assistant class. My foodstamps is about $876 \$$ a month, my cash aid is 756 now my dude see me doin hecka good just axed me to merry him?? Do any of y'all know how I get a prenup? Cause If this don't work out I don't wanna have to split my section8 and other benefits I've worked hard for.

The meme became the focus of a Snopes query ${ }^{3}$, as readers of the myth-busting site (Snopes.Com) asked if such a person actually existed. Snopes.com concluded, "While the question genuinely might have been asked (by some person at some point somewhere on the Internet), it's equally probable that the meme was fabricated to mock recipients of public assistance" (Snopes 2015, see footnote 2).

\footnotetext{
${ }^{2}$ All meme texts were reproduced verbatim including spelling and grammatical errors.

3 http://www.snopes.com/politics/satire/section8.asp
} 


\subsection{The Welfare Fraud Meme}

The theme of the 'welfare fraud' meme includes images that portray those receiving social assistance as 'cheating' the system in some way, such as not being disabled, not reporting income, or collecting multiple welfare checks under false names. This is one of the most common and most widely distributed poverty-bashing memes circulating online. Most of these memes are based mostly on text, often under twenty words, and usually include a simple picture, since the emphasis is on the text. A recurring fraud meme is a variation of the claims that welfare recipients misuse food stamps, wear designer make up and designer clothing while driving expensive vehicles to pick up their welfare check, have excessively large families in order to receive additional benefits, own smartphones, fake disabilities and spend the social assistance money in ways which suggest they are not actually economically deprived and are, therefore, 'cheating' the system. Most illustrative texts include:

I went to sign my dog up for welfare. They said he's not eligible. I said he's lazy, unemployed, and doesn't know his daddy. He gets his check next week.

and:

Glad I caught you hoppin' out of your Cadillac checkin' your Rolex. Here's your Welfare check!

and:

Welfare was never intended to be a career opportunity.

When the welfare fraud memes include a picture, they often feature an unflattering image of someone in poverty, for example, a young male wearing a mullet, with a piece of straw hanging out of the corner of his mouth, shirtless and leaning against a truck, with the caption: "Complains That He Can't Feed His Kids... Sells Food Stamps For Beer." This particular meme not only suggests welfare fraud, but also that this person in poverty is also depriving their children of food in order to feed his alcohol addiction. Additionally, by featuring a young-looking able-bodied male, it also suggests 'fraud' as he appears 'unworthy' of governmental support. His leaning against the truck suggests he owns it, which further contributes to the fraud theme: why is he receiving government assistance if he also appears to own a vehicle? His exposed upper torso, with his hairy chest, adds to the negative stereotyping of those living in poverty by presenting him as shirtless in public. Here, the image that accompanies the text serves to anchor the message in a way that reiterates that the welfare recipient is not deserving.

Some memes also normalise the assumption that welfare fraud is rampant and common. This one, for example, consists only of text, all in capital letters:

IF YOU ARE RECEIVING GOVERNMENT HANDOUTS AND YOU HAVE A CELL PHONE, CABLE TV, A COMPUTER, A \$400 PER MONTH CAR PAYMENT YOU ARE A PERPETUAL SOCIETAL LEECH AND SHOULDN'T BE ALLOWED TO VOTE. 
The use of capital letters 'shouts' the message out at the viewer, making it seem more urgent and important, and also by making such claims, that some of those receiving governmental social assistance are actually comparable to many of the working class, and sets the viewer up to resent those who are receiving these 'handouts.'

\subsection{The Lazy Welfare Recipient' Meme}

Although there are some overlapping themes, particularly between the "welfare fraud" and the "lazy welfare recipient" memes (see table for detailed breakdown) the theme of the 'lazy welfare recipient' meme is that those on social assistance simply do not want to work, that they choose welfare over a job as they are 'lazy' and prefer to stay home and collect a monthly check from the welfare office over going out and finding a job.

Examples of these memes include framing those on welfare assistance as choosing not to work and instead, because of 'laziness,' being content to stay home and do nothing while living on the financial aid of governmental assistance. These memes are consistent in framing welfare as an alternative choice of the welfare recipient to working, and framing this notion with accompanying text which often encourages the viewer to feel resentment and anger at the 'lazy' welfare recipient. A common example: "Let's tax a working man almost to his breaking point then give it to someone who refuses to work... said no Founding Father ever." This meme features the image of a frowning George Washington on the side of the text, also reinforcing the idea that this 'laziness' goes against the American work ethic and dream of being rewarded for one's hard work and labour. As Williamson (1978) would argue, it is often the juxtaposition of otherwise unrelated objects that can symbolically imbue one object with the value associated with the other. In this instance, the combination of George Washington with the text means that they become associated with each other, and George Washington's image somehow gives more credibility to the meme's claim of the 'lazy' poor.

Pictures of animals are popular in poverty-bashing memes, as they include humour and mock the poor in a very particular way in which the animal 'stands in' for some of the worst stereotypes of those living in poverty. For example, the "Welfare Cat" meme features an obese cat sitting up, in the manner of a 'fat' human adult, on a couch surrounded on either side by junk food and empty pop bottles lying on their side. The cat, with its large and overflowing bowl of chips sitting close by on the couch, is holding a remote control and is staring intently at what is assumed to be a television screen. The caption reads:

WELFARE CAT: Can't you guys come up with a website or something? Having to go pick up my check once a month is a pain in the butt.

This meme represents and perpetuates many of the negative stereotypes about those on social assistance, including that the poor sit around on couches, watching television and eating junk food all day, while trying to think up additional ways to make receiving their welfare check even easier. An additional meme including the use of an animal, referenced earlier, features an image of a large dog, sitting quietly to the side of the meme's text, which states:

I went to sign my dog up for welfare. They said he's not eligible. I said he's lazy, unemployed, and doesn't know his daddy. He gets his check next week. 
This particular meme uses a black background, with a light grey frame for the text. The text itself is in black, which makes it stand out particularly well against the light grey. The image of the dog is simple: it is being used in some way, but not so as to distract from the meme's message of the lazy poor. In other words, the image in this meme is less important: the text does not require the image for interpretation. This meme also refers to another common stereotype about those living in poverty, namely the notion that mothers on welfare are promiscuous with poor judgment, which is why the children of welfare recipients "don't know their daddy."

\subsection{The 'Undeserving Poor' Meme}

The theme of the 'undeserving poor' meme is that some people living in poverty are more worthy of governmental assistance than others, and conveys explicit judgment about who is not 'worthy'. The contrasting 'deserving' poor often include children and the elderly. Messages relating to the 'deserving' poor might appear somewhat positive on the surface - they are often sympathetic towards people living in poverty - but they are still problematic for several reasons. They are condescending and patronising, typically 'othering' the poor as helpless victims. They position only particular people - children, the elderly, or a romanticised image of a person living in poverty as deserving of aid. This again individualises the problem as it suggests that only certain people, because of particular attributes society judges as worthy, have earned the help of the state. Further, there is inherent judgment for anybody who does not supposedly embody traits that make them more innocent, more sympathetic, and ultimately, worthy of concern.

An example of the undeserving poor meme includes one that resembles an official warning sign, often seen in public parks containing animals such as bears, deer and other wildlife. This particular meme looks authentic as it features the same colours and script that are normally used on a type of governmental sign that is warning the public to be aware of a potential threat. The sign states, all in capital letters:

\section{PLEASE DO NOT FEED THE PARK ANIMALS. THEY BECOME DEPENDANT AND WILL SOON WANT CELL PHONES.}

This is a common example of the 'undeserving poor' meme, as it conveys some of the negative stereotypes of those living in poverty, including that they become dependent on the system and gain expectations beyond what they 'deserve'. There is also the subtler representation of those living in poverty as 'wild animals' that require a large governmental billboard to 'warn' the general public of the danger they apparently represent. This widespread assumption of those receiving welfare assistance as 'undeserving' is also revealed in another common meme which suggests many of those receiving assistance are not only 'undeserving,' but also demands 'proof' that they are: one such features a drawing of a man sitting in front of his computer, scratching his head as if confused. The text states:

For all the taxes they take out of my paycheck, the least they can do is send me a picture of the ghetto family l'm supporting to hang on my fridge.

The use of the phrase "ghetto family" carries racial connotations, normalising the stereotype of those living in poverty as being from the 'ghetto,' suggesting a culture of 
poverty, while a picture - almost like a trophy - of the "family I'm supporting" is demanded.

Another common theme of the 'undeserving poor' meme is one which clearly defines the criteria of whom should be receiving assistance, and who should not:

NEWS FLASH: If you do not work and are not disabled, but you're on welfare, you are NOT a 'stay-at-home Mom,' YOU are unemployed, sucking off the system and in need of a job! Get on it!

And also: "If you need welfare to feed your kids, don't get anymore tattoos, manicures, weaves, or face piercings". Both of these suggest certain welfare recipients and parents who are particularly undeserving and worthy of surveillance in terms of their choices of what to spend their social assistance on.

Similar to those examples is the meme which, in addition to passing judgment on who is 'deserving', critiques what the 'undeserving' spend their welfare checks on, and seems primarily focused on presenting those living in poverty as spending their limited, 'unearned' social assistance on non-essential 'luxuries' such as cell phones and tattoos. Examples include:

Why the fuck would you buy an iPhone if you're on welfare?

and:

Someday I hope to be able to afford a new iPhone... like the girl in front of me with the food stamps

and:

So that's why I work so many hours, so you can collect welfare, wear PJ's in public and have an iPhone.

There is almost an obsessive focus on iPhones as the symbol - or proof - of the 'undeserving poor', since they are evidence, according to the meme, that one is obviously 'undeserving' of social assistance if one owns an iPhone.

\subsection{The 'Punitive of the Poor' Meme}

The theme of the 'punitive of the poor' meme insists on accountability for those whom receive social assistance by demanding a requirement of drug testing, and, since it is viewed as further evidence of being part of the 'undeserving poor', insisting that those in poverty not be 'allowed' to have tattoos or cell phones, focusing on ways to humiliate and control those in poverty.

We examined numerous memes that repeat similar themes about how to humiliate and control those who receive social assistance by forcing accountability and exerting control on those living in poverty. For example, a common meme is one which features text only and states:

If you can afford beer, cigarettes, new tattoos, drugs, and cable TV... Then you don't need food stamps or welfare. SHARE this if you agree. 
This particular meme encourages poverty-bashing by suggesting the viewer click 'like' and share the meme more widely on Facebook, helping to spread the meme's message among the widest audience possible. Unlike the other poverty-bashing memes, such as the 'fraud', 'undeserving' and 'lazy' memes, the 'undeserving poor' meme often includes a component of directly suggesting the viewer share it on social media, including Facebook and Twitter. These memes tend to include text only, and often feature bolded letters which, in addition to critiquing the poor as being fraudulent, lazy, and undeserving as the other memes do, also often include a call for action of some sort against those on social assistance, and are quite aggressive in their language choice. For example, one of the most common 'punitive' memes is that welfare recipients should be subjected to drug testing. This one, which appeared five times out of eight memes coded, is illustrative of a meme that demands welfare recipients be drug tested:

\section{YOU SHOULD HAVE TO PASS A DRUG TEST TO RE- CEIVE A WELFARE CHECK...BECAUSE I HAD TO PASS ONE TO EARN IT FOR YOU.}

As with most of the punitive memes, this one is text only and encourages the viewer to 'like' and 'share' it across social media. Teruggi Page $(2006,91)$ argues that, "in our mediated world [...] texts are decidedly visual expressions of culture and society". Applied in the context of poverty memes, this observation suggests focus on encouraging the viewer to join in the 'bashing' by spreading these texts. The visual components of the memes in our sample are not the memes' primary messages; rather they serve as a vehicle for circulation in what is an increasingly visual digital culture. These attacks on the poor, which poverty-bashing memes represent, are able to circulate and propagate widely, unchallenged, across digital platforms on social media.

\subsection{The 'Critical of the Larger System' Meme}

The last theme we identified included 17 of our 59 memes. This category offered messages that are less critical of the poor and instead offer critiques of government agencies, of the corporate culture of neoliberalism, and of those who are disrespectful of welfare recipients. For example, one meme states:

Corporations avoid 90 billion dollars in tax revenue and no one bats an eye. One person abuses welfare and everyone loses their mind.

Another addresses the reader directly:

While you are busy bitching about the guy who bought a Snickers with his food stamps, Exxon pocketed $\$ 9000$ of your tax dollars.

Yet another meme shows an image of the former US presidential candidate Mitt Romney with this caption:

Says people on welfare are lazy and government dependent. Forgets that military veterans, people with jobs and his father were on welfare. 
These memes are clearly less concerned with the character of those in receipt of social assistance, and their own feeling of being victimised and more dismayed by the political rhetoric that is characteristic of the neoliberal order.

\section{Conclusion}

Memes that mock, humiliate, and 'bash' those living in poverty confirm, legitimise, and reproduce relations of power and dominance in society. Those who are already comfortable with stereotypes find stereotyping memes socially acceptable (Duchscherer and Dovidio 2016) suggesting that circulation of such memes reinforces social prejudice. People living in poverty often lack access to numerous social resources that the more privileged and dominant groups in society take for granted, and also lack control over how social issues and topics are dealt with (van Dijk 2011; Hick et al. 2008; Mehra et al. 2004; Parsons and Hick 2008; Quark 2008). They may also lack the necessary information in order to challenge the discourses around and about them (Hick et al. 2008; Quark 2008; Wodak 1987). Meanwhile, popular discourses such as viral social media content rapidly reproduce social norms, further entrenching the dominant values. What our findings indicate is that rather than simply ushering forward unprecedented democratisation of discourse (Tapscott and Williams 2006; Shirkey 2008), the age of social media has in many ways worked to reinforce dominant norms and further promote neoliberal values. This is no longer a topdown process, but a collective effort of the digital grassroots - an epitome of hegemonic process.

With respect to poverty and social assistance, our findings point to five main themes that are reproduced in poverty-bashing memes: that those who live in poverty and receive social assistance are frauds; that they are lazy; that they are undeserving; that they need to be punished; and finally, that the larger economic system is to blame. In all cases, however, there is a strong overtone that the authors (and distributors) of the memes feel themselves victimised by the system, and that they view the recipient of social assistance as taking advantage of (or victimising) other 'ordinary' people. This discursive trend has two important implications. First, it contributes to the 'blame-game' that adds to the marginalisation of those who live in poverty, because poverty is presented in these memes as the result of individual shortcomings or failures. Second, they further contribute to individualisation of poverty, ensuring that the systemic causes of poverty remain under-examined, since poverty is not presented as the result of structural inequalities in society.

There is a substantial body of literature that examines the systemic causes of poverty. Understanding discursive trends that by their sheer simplicity work to overshadow such literature and promote neoliberal constructs of poverty can be helpful in devising more effective ways to communicate the systemic realities. But countering such discourses is a difficult task and our findings leave us less than optimistic. Nevertheless, our findings may be useful to those who tirelessly seek ways to address the systemic underpinning of poverty. Social media makes all of us more likely to seek and access only information that fits with our worldview (Couldry and Turrow 2014). The risk here is that reproduction of antagonistic and marginalising discourses serves to normalise them (Milner 2013a). If how we talk about poverty shapes how we address it as a society, venturing into the digital landscape of discourses that challenge the way we see the world can be helpful in understanding and addressing misconceptions and judgements - of poverty and of a range of other social justice issues. 


\section{References}

Barthes, Roland. 1977. Rhetoric of the Image. In Image - Music - Text (translated by Stephen Heath), 32-51. New York: Hill and Wang.

Baym, Nancy. 2010. Personal Connections in the Digital Age. Cambridge: Polity.

Berger, Jonah and Katherine Milkman. 2010. Social Transmission, Emotion, and the Virality of Online Content. Marketing Science Institute Working Paper Series 2010 Report No. 10114. Accessed 23 November 2016. http://marketing.wharton.upenn.edu/documents/research/Virality.pdf.

Broersma, Marcel and Todd Graham. 2012. Social Media as Beat: Tweets as a News Source During the 2010 British and Dutch Elections. Journalism Practice 6 (3): 403-419.

Bullock, Heather E., Karen Fraser Wyche, and Wendy R. Williams. 2001. Media Images of the Poor. Journal of Social Issues 57 (2): 229-246.

Burgess, Jean and Joshua Green. 2009. YouTube: Online Video and Participatory Culture. Cambridge: Polity Press.

Chen, Carl. 2012. The Creation and Meaning of Internet Memes in 4chan: Popular Internet Culture in the Age of Online Digital Reproduction. Habitus 3: 6-19.

Couldry, Nick and Joseph Turow. 2014. Advertising, Big Data, and the Clearance of the Public Realm: Marketers' New Approaches to the Content Subsidy. International Journal of Communication 8: 1710-1726.

Cunningham, Brent. 2004. Across the Great Divide: Class. Columbia Journalism Review 43 (1): 31-38.

Davis, Corey. B., Mark Glantz and David R. Novak. 2016. "You can't run your SUV on cute. Let's go!": Internet Memes as Delegitimizing Discourse. Environmental Communication 10(1), 62-83.

Dawkins, Richard. 2006/1976. The Selfish Gene. Oxford: Oxford University Press. 30th Anniversary Edition.

Duchscherer, Katie M. and John F. Dovidio. 2016. When Memes are Mean: Appraisals of and Objections to Stereotypic Memes. Translational Issues in Psychological Science 2 (3): 335-345.

Duggan, Maeve. 2015. Social Media Update 2014. Pew Research Internet Project. January 9.

Hadley, Bree. 2016. Cheats, Charity Cases and Inspirations: Disrupting the Circulation of Disability-Based Memes Online. Disability \& Society 31 (5): 676-692.

Harrison, Claire. 2003. Visual Social Semiotics: Understanding How Still Images Make Meaning. Technical Communication 50 (1): 46-60.

Hick, Steven, John Graham and Marion Jones. 2008. Navigating the Digital Divide. Currents: New Scholarship in the Human Services 7 (1): 1-13.

Fairclough, Norman. 2000. Language and Neoliberalism. Discourse and Society 11(2): 147148.

Fleras, Augie. 2011. The Media Gaze: Representations of Diversities in Canada. Vancouver: UBC Press.

Herman, Edward and Noam Chomsky. 2002. Manufacturing Consent: The Political Economy of the Mass Media ( $6^{\text {th }}$ ed.). : New York: Pantheon Books.

Heylighen, Francis. 1996. Evolutions of Memes on the Network: From Chain-Letters to the Global Brain. In Memesis: The Future of Evolution, edited by Gerfried Stocker and Christine Schöpf, 48-57. Vienna: Springer.

Hristova, Stefka. 2014. Visual Memes as Neutralizers of Political Dissent. Triple C: Journal for a Global Sustainable Information Society 12 (1): 265-276.

Jenkins, Henry. 2006. Convergence Culture: Where Old and New Media Collide. New York: New York University Press. 
Johnson, Bonnie and Germaine Halegoua. 2015. Can Social Media Save a Neighborhood Organization? Planning, Practice \& Research 30 (3): 248-269.

Kelly, Maura. 2010. Regulating the Reproduction and Mothering of Poor Women: The Controlling Image of the Welfare Mother in Television News Coverage of Welfare Reform. Journal of Poverty 14: 76-96.

KhosraviNik, Majid and Johann W. Unger. 2015. Critical Discourse Studies and Social Media: Power, Resistance and Critique in Changing Media Ecologies. In Methods of Critical Discourse Studies (3rd ed.), edited by Ruth Wodak and Michael Meyer, 205-233. London: SAGE Publications.

Kien, Grant. 2013. Media Memes and Prosumerist Ethics: Notes Toward a Theoretical Examination of Memetic Audience Behaviour. Cultural Studies \& Critical Methodologies 13 (6): 554-561.

Kim, Young-Chul and Greg C. Loury. 2014. Social Externalities, Overlap and the Poverty Trap. The Journal of Economic Inequality 12 (4): 535-554.

Knezevic, Irena, Heather Hunter, Cynthia Watt, Patricia Williams, and Barbara Anderson. 2014. Food Insecurity and Participation: A Critical Discourse Analysis. Critical Discourse Studies 11 (2): 230-245.

Knobel, Michele and Colin Lankshear, eds. 2007. Online Memes, Affinities and Cultural Production. New York: Peter Lang Publishing, Inc.

Koenig, Thomas. H. and Michael L. Rustad. 2015. Digital Scarlet Letters: Social Media Stigmatization of the Poor and What Can Be Done. Nebraska Law Review 93 (3): 592-635.

Kwasnik, Barbara and Kevin Crowston. 2005. Genes of Digital Documents: Introduction to the Special Issue. Information, Technology \& People 18(2): 76-78.

Lange, Patricia G. 2009. Videos of Affinity on YouTube. In The Youtube Reader, edited by Pelle Snickars and Patrick Vonderau, 228-247. Stockholm: Wallflower Press.

Lens, Vicki. 2002. Welfare Reform, Personal Narratives and the Media. Journal of Poverty 6 (2): $1-20$.

Lister, Ruth. 2004. Poverty. Cambridge: Blackwell/Polity Press.

MacKinnon, Shauna. 2013. Decolonizing Employment: Aboriginal Inclusion in Canada's Labour Market. Winnipeg: University of Manitoba Press.

Mantler, Gordon. 2010. "The press did you in": The Poor People's Campaign and the Mass Media. The Sixties: A Journal of History, Politics and Culture 3 (1): 33-54.

Marston, Greg. 2008. A War on the Poor: Constructing Welfare and Work in the Twenty-first Century. Critical Discourse Studies 5(4): 359 - 370.

Marwick, Alice. 2013. Jargon: Key Concepts in Social Research: Memes. Contexts 12 (4): 12-13. Accessed 8 November 2016. https://contexts.org/articles/memes/

Mehra, Bharat, Cecelia Merkel and Ann Peterson Bishop. 2004. The Internet for Empowerment of Minority and Marginalized Users. New Media \& Society. Vol 6 (6): 781-802.

Messaris, Paul. 1997. Visual Persuasion: The Role of Images in Advertising. Thousand Oaks, CA: Sage.

Milner, Ryan. 2013a. FCJ-156 Hacking the Social: Internet Memes, Identity Antagonism, and the Logic of Lulz. The Fibreculture Journal 22: 62-92.

Milner, Ryan. 2013b. Pop Polyvocality: Internet Memes, Public Participation, and the Occupy Wall Street Movement. International Journal of Communication 7: 2357-2390.

Mina, An Xiao. 2014. Batman, Pandaman and the Blind Man: A Case Study in Social Change Memes and Internet Censorship in China. Journal of Visual Culture 13(3): 359375.

Mosse, David. 2010. A Relational Approach to Durable Poverty, Inequality and Power. The Journal of Development Studies 46(7): 1156-1178.

Nahon, Karine and Jeff Hemsley. 2013. Going Viral. Cambridge: Polity Press.

Nichols, Bill. 2003. The Work of Culture in the Age of Cybernetic Systems. In The New Media Reader, edited by Noah Wardrip-Fruin and Nick Montfort, 625-642. Cambridge, MA: The MIT Press. 
Nielsen, Greg. 2008. Conditional Hospitality: Framing Dialogue on Poverty in Montreal Newspapers. Canadian Journal of Communication 33 (4): 605-619.

Nooney, Laine and Laura Portwood-Stacer. 2014. One Does Not Simply: An Introduction to the Special Issue on Internet Memes. Journal of Visual Culture 13 (3): 248-252.

Parsons, Cheryl and Steven Hick. 2008. Moving from the Digital Divide to Digital Inclusion. Currents: New Scholarship in the Human Services 7 (2): 1-13.

Power, Elaine M. 2005. The Unfreedom of Being Other: Canadian Lone Mothers' Experiences of Poverty and Life on the Cheque. Sociology 39(4): 643-660.

Quark, Amy. 2008. Social Exclusion in the New Economy: Beyond the Digital Divide. Currents: New Scholarship in the Human Services 7 (2): 1-16.

Redden, Joanna. 2011. Poverty In The News: A Framing Analysis of Coverage in Canada and the UK. Information, Communication \& Society 14(6): 820-849.

Reuters Institute. 2016. Digital News Report 2016. Oxford: UK Reuters Institute for the Study of Journalism at Oxford University.

Segev, Elad, Asaf Nissenbauum, Nathan Stolero and Limor Shifman. 2015. Families and Networks of Internet Memes: The Relationship between Cohesiveness, Uniqueness, and Quiddity Concreteness. Journal of Computer-Mediated Communication 20 (4): 417-433.

Shifman, Limor. 2011. An Anatomy of a YouTube Meme. New Media \& Society 14 (2): 187203.

Shifman, Limor. 2013. Memes in a Digital World: Reconciling with a Conceptual Troublemaker. Journal of Computer-Mediated Communication 18 (3): 362-377.

Shifman, Limor. 2014. The Cultural Logic of Photo-Based Meme Genres. Journal of Visual Culture 13 (3): 340-358.

Shirkey, Clay. 2008. Here Comes Everybody. New York: Penguin.

Statista Statistics. 2016. Number of Internet Users Worldwide. The Statistics Portal. Accessed 30 November 2016. http://www.statista.com/statistics/273018/number-of-internetusers-worldwide/

Swanson, Joanna. 2001. Poor-bashing: The Politics of Exclusion. Toronto: Between the Lines.

Teruggi Page, Janice. 2006. Myth and Photography in Advertising: A Semiotic Analysis. Visual Communication Quarterly 13 (2): 90-109.

Tapscott, Don and Anthony D. Williams. 2006. Wikinomics: How Mass Collaboration Changes Everything. Old Saybrook, CT: Tantor Media.

van Dijk, Teun A. 2011. Discourse Studies: A Multidisciplinary Introduction (2nd ed.). Thousand Oaks, CA: Sage Publications.

van Dijck, Jose and Thomas Poell. 2013. Understanding Social Media Logic. Media and Communication 1 (1): 2-14.

van Leeuwen, Theo. 2009. Discourse as the Recontextualization of Social Practice: A Guide. In Methods of Critical Discourse Analysis (2nd ed.), edited by Ruth Wodak and Michael Meyer, 144-161. Los Angeles: SAGE Publications.

Wang, Jiayu. 2014. Criticising Images: Critical Discourse Analysis of Visual Semiosis in Picture News. Critical Arts 28 (2): 264-286.

Westerman, David, Patric Spence and Brandon Van Der Heide. 2014. Social Media as Information Source: Recency of Updates and Credibility of Information. Journal of Computer-Mediated Communication 19 (2): 171-183.

Williamson, J. 1978. Decoding Advertisements: Ideology and Meaning in Advertising. New York: Marion Boyars Publishers.

Wodak, Ruth. 1987. Language, Power and Discourse and Society: Assessing Cognitive Approaches in CDA. London: Sage.

Yoon, InJeong. 2016. Why is it not just a joke? Analysis on Internet Memes Associated with Racism and Hidden Ideology of Colorblindness. Journal of Cultural Research in Art Education 33: 92-123. 


\section{About the Authors}

Kathy Dobson

Kathy is a Vanier Scholar with extensive experience as a journalist, and PhD candidate at Carleton University.

Irena Knezevic

Irena is an assistant professor in communication, culture and health at Carleton University. 